\title{
Adat Movements for Environmental Justice: the Case of Benoa Bay Bali
}

\author{
Slamet Subekti ${ }^{1 *}$, Singgih Tri Sulistiyono ${ }^{1}$, and Dedi Adhuri ${ }^{2}$ \\ ${ }^{1}$ Department of History, Faculty of Humanities, Universitas Diponegoro, Indonesia \\ ${ }^{2}$ Social and Cultural Research Center, Indonesian Research Institute, Indonesia
}

\begin{abstract}
This paper is the result of a literature study on environmental justice, adat movements, and adat perspectives of Tri Hita Karana related to the Benoa Bay reclamation project, and in-depth interview with the coordinator of ForBALI I Wayan "Gendo" Suardana. The discussion begins on environmental justice is a central issue in Indonesia. Then the discussion of the Benoa Bay reclamation project into a tourist development area, which has the potential to threaten maritime conservation and loss of livelihoods of local residents. Furthermore, the discussion about Tri Hita Karana as adat perspectives that underlies the movement of indigenous peoples to reject reclamation project. Finally, the discussion about the ForBALI movement as a representation of indigenous peoples who reject the reclamation project in Benoa Bay. Based on the discussion it was concluded that, adat movements through ForBALI has temporarily succeeded in thwarting the reclamation project at Benoa Bay by PT TWBI. The adat perspective on Tri Hita Karana became the philosophical basis of the ForBALI movement. The ForBALI movement has succeeded in integrating the environmental movement, political movement and cultural movement into the spirit of resistance of indigenous peoples in facing the hegemony of the power of neoliberal capitalism.
\end{abstract}

Keywords: Environmental Justice; Tri Hita Karana; ForBALI, Reclamation; Benoa Bay Bali.

\section{Introduction}

Discussion of adat movements for environmental justice in the Benoa Bay of Bali brought our attention to a number of figures, including ForBALI Coordinator I Wayan "Gendo" Suardana with WALHI Bali activists, Jerinx musicians and the band "Superman Is Dead", the academicians Dr. L.G. Saraswati Putri (UI) and Agung Wardana Ph.D (UGM) as well as thousands of indigenous people in Bali and beyond, national and international NGOs and sympathizers. The big story of this paper is about environmental issues, with the theme of environmental justice that specifically focuses on the Benoa Bay reclamation case.

* Corresponding author: slametsubekti01@gmail.com 
This environmental issue is relevant because Indonesia is currently still in an ecological emergency. This is indicated by the domination of the land and sea area of Indonesia which is still dominated by extractive industry interests. This domination of spatial control and bad environmental management practices has left Indonesia in an ecological emergency [1].

This fact of ecological emergency can be seen from (1) the quantity of ecological disasters that are still high; (2) the high quantity of natural resource conflicts that are not followed by good conflict resolution policies; (3) pollution conditions in watersheds and water sources that are getting worse and worse; (4) coastal and small island management policies that still favor investment interests, a concrete example can be seen from the reclamation policy; and (5) the condition of law enforcement which still shows its partiality to investors and tends to scapegoat the people.

While for regulatory policy, the issuance of good legal regulations is derived in the form of ambiguous technical regulations. State actors still carry out a double-faced policy, on the one hand populistly declaring its alignments to the people, but in its implementation it is still dominant in favor of investment interests. As for the corporation, it still maintains the expansive and greedy nature, in which several state policies that favor ecological justice are opposed by various systematic efforts, both through legal channels; carrying out massive political intervention through parliament; and piggybacking on state policy to save its interests. On the other hand, the people are slowly becoming aware of their constitutional rights and are using them to cloud policies that neglect environmental and human rights aspects.

The discussion of this paper begins with the issue of environmental justice being a central issue in Indonesia. This issue involves the state, corporate, and society as actors. In the case of the Benoa Bay reclamation plan, the contestation took place between the indigenous community and the investors of PT TWBI facilitated by regulation by the government. The discussion concludes with the actions of the adat movement based on the philosophy of Tri Hita Karana dealing with the hegemonic power of neoliberal capitalism.

\section{Central issue on Environmental Justice}

In connection with these environmental issues, the theme of environmental justice needs urgent attention. Environmental justice as a right to obtain intergenerational justice that pays attention to the principles of gender justice, the principle of people's safety, sustainability of natural services and protection of people's productivity. In principle, all generations, both now and in the future, men and women have the right to be saved from the threat of impact and crisis, as well as the destruction of the environment and the sources of people's lives. Thus, environmental justice is a struggle towards the balance of nature and humans without mastery for intra and intergenerational interests [2].

The key question in the context of environmental justice is who are the actors of environmental destruction? According to WALHI's analysis, the highest environmental destruction actors are corporations, especially those who invest in the mining and plantation sectors. The second actor is the government and the third actor is a combination of corporation and government, and the last actor is from the community. These findings further strengthen civil society to continue to urge corporate responsibility for environmental crimes that have been committed. Field data shows the collaboration of corporations and state officials that strengthens the previous analysis that environmental problems cannot be separated from the attachment or consolidation that is increasingly strengthened between the interests of capital and power (the economic and political ropes of power). Whereas the community as an actor is found in unconventional mines with a high level of risk, and the omission process carried out by the government without providing alternative sources of livelihood. This fact also breaks the assumption or stigma that the 
actors of environmental destruction are the poor, and poverty is the cause of environmental damage (WALHI, 2013), please referee Table 1 about the details.

Table 1. A number of Environmental Damages in Bali

\begin{tabular}{|c|c|}
\hline Environmental Problems & Evidences \\
\hline Deforestation & $\begin{array}{l}\text { As many as } 20 \% \text { of the total } 130,000 \text { hectares of } \\
\text { forests in Bali suffered critical damage. Meanwhile, } \\
\text { land clearing and illegal logging continue. }\end{array}$ \\
\hline Flora and fauna & $\begin{array}{l}\text { Noted } 41 \text { plant species and } 47 \text { animal species in Bali } \\
\text { range from extinction. }\end{array}$ \\
\hline Land degradation & $\begin{array}{l}\text { Nearly } 20 \% \text { of Bali's land has eroded on a heavy } \\
\text { scale. }\end{array}$ \\
\hline Air pollution & $\begin{array}{l}\text { Lead, nitrous oxide and CO materials in urban areas } \\
\text { are at a level not safe for public health. }\end{array}$ \\
\hline Sea water pollution & $\begin{array}{l}\text { The content of ammonia, lead, and other heavy } \\
\text { materials in the Sanur, Kuta and Lovina Beach areas } \\
\text { is above the level of the seawater's reasonableness. }\end{array}$ \\
\hline River water pollution & $\begin{array}{l}\text { A number of rivers in the Badung and Buleleng areas } \\
\text { are polluted by E-coli and phosphate bacteria with } \\
\text { quite dangerous content. }\end{array}$ \\
\hline Garbage and waste & $\begin{array}{l}\text { One thousand tons of garbage / waste per day and } \\
25 \% \text { of it is non-organic waste. }\end{array}$ \\
\hline Coral reefs & $\begin{array}{l}\text { Noted } 25 \% \text { of coral reefs are in critical condition. } \\
\text { Only } 35 \% \text { were recorded in good condition. }\end{array}$ \\
\hline Mangrove & $\begin{array}{l}\text { Mangrove forest damage mostly occurs in tourist } \\
\text { areas, such as Sanur, Nusa Dua, and Serangan. }\end{array}$ \\
\hline
\end{tabular}

Source: Lewis \& Lewis, 2009, p. 71

The target of the protests carried out by civil society which is mostly carried out by NGOs and the public is the government, this is related to various policies issued by the state management both at national and regional levels. The insistence on change is the main agenda that continues to be driven by community protests. This shows the relationship between policies issued by the state and environmental problems faced by the community. The policy actually becomes the legitimacy for corporations to conduct corruption with a "stamp" from the government through legislation, regulation and licensing.

The next target of protest is the corporation or company in the concession, which is the target of protests by residents. This shows that the people actually began to be "literate" with their rights and also began to understand the law, and began to understand the roots of the problems experienced, and find out who the actors and interests are. This cannot be separated from the work carried out by civil society to continuously carry out critical education to the community through organizing in the villages.

It is important to be aware of the latest developments in capitalism with its ability to transform itself to respond to crises and potential crises caused by internal contradictions, not least in this Neoliberal era. The environmental crisis and social problems caused by capitalism are quickly transformed into new opportunities for the expansion of capital accumulation in order to maintain its sustainability. As a result, capitalists emerged who presented themselves as human beings and saviors of the environment as a contemporary strategy to reduce social resistance. This strategy is at once to blur the dichotomy boundaries between charity and profit-making, as well as private and public, so that the operation of capitalism which has been limited to private arrows opens new maneuvering spaces on all lines of life (Wardana, 2017). 


\section{Reclamation of Benoa Bay}

The Benoa Bay reclamation plan has been a complicated debate in Balinese society for the past seven years. How not, the plan to build resorts and other tourism facilities on 700 hectares of land is full of various polemics. The status of the Benoa Bay which is a conservation zone, the birth of a Governor's Decree, until the Presidential Regulation shows the interests that are not kidding. As for the debates that arose not only highlighted environmental issues, but also economic, social, to religious issues and the customs of the Balinese people.

Benoa Bay is administratively located in cross-regency / city waters namely Denpasar City and Badung Regency, included in three sub-districts namely South Denpasar, Kuta and South Kuta. The waters of the Gulf are surrounded by 12 villages / kelurahan, each with 6 villages / kelurahan in Denpasar City and Badung Regency. Benoa Bay is a tidal waters, located in the southern hemisphere of Bali. The waters of the Benoa Bay after the reclamation of Serangan Island are typologies of semi-closed bays because the bay mouth has narrowed to $75 \%$. Theoretically, the area of Benoa Bay waters measured on the outermost side of the coastline is 1,988.1 ha, can be divided into 3 zones, namely zone 1 (zone with bay mouth line drawn from the harbor of Benoa Harbor and Tanjung Benoa) covering 1,668.3 ha, zone 2 (zone between Benoa Harbor and Serangan Island) covering 231.3 ha, and zone 3 (zone between Suwung Kangin and Serangan Island) covering 88.5 ha [3]

The phenomenon of environmental neoliberalisation and natural resources related to the development of the Benoa Bay watershed, Bali. Neoliberalisation is not only aimed at rearranging state, market and community relations. More than that, neoliberization also intends to change the relationship between humans and their environment. This process is an integrated part of the current system of capitalism to look for spatial fixes and environmental fixes in overcoming the production crisis $[4,5]$.

This search itself is carried out by (1) penetrating the paradigm of environmental preservation based on free-market environmentalism, a belief that environmental preservation can be done more effectively and efficiently through privatization and commercialization of the environment and natural resources; (2) the commodification of goods and services that were not commodities, for example the introduction of carbon trading mechanisms; (3) capitalization of disasters by making disasters, crises, or potential disasters a justification for intervention and capital accumulation; and (4) transformation of the role and function of the state in environmental governance (Castree 2008).

Thus, neoliberalism does not really mean to eliminate the role of the state, but it does require the transformation of the state as an arrangement and guarantor of the operation of the market while expanding it to cover all aspects of life [6].

Benoa Bay is a semi-enclosed waters area that lies on the southern peninsula of Bali. Because of its position among the golden tourism triangle of Bali (Nusa Dua, Kuta and Sanur), the Benoa Bay area is often the target of investments that want to take advantage of the geographical advantage. Under the New Order regime, the era in which Bali became the "Jakarta Colony" (Aditjondro 1995), there were at least two investments that wanted to develop exclusive tourism in the Benoa Bay, namely PT Bali Turtle Island Development (BTID) and PT Bali Benoa Marina (BBM).

Both companies are owned by Suharto's relatives who are familiarly called the Cendana Family. PT BTID is a consortium company led by Bimantara Group owned by Suharto's son, Bambang Trihatmodjo, a Gajah Tunggal group owned by his sister, Siti Hardiyanti Rukmana, and PT Pembangunan Kartika Udayana, owned by Kodam IX Udayana. While PT BBM is a joint venture between Hampuus Group owned by another Suharto son, 
Hutomo Mandala Putra (Tommy Soeharto), with PT Mandira Erajasa Wahana Transportation Aerowisata, one of the divisions of Garuda Indonesia [7, 8].

The case of the Benoa Bay reclamation plan has become a culmination of various environmental problems in Bali due to tourism development in at least the last five years. Bali's environmental problems due to tourism activities do not only cover water areas. In 2007, the Center for Environmental Studies at Udayana University elaborated data on Bali's environmental damage that included a number of habitats and ecosystems.

\section{Perspectives: Tri Hita Karana}

The strong influence of Hinduism and spiritual aspects in Balinese society also influenced the expansion of the involvement of indigenous peoples in the "Bali Reject Reclamation" movement. From an indigenous perspective, the Benoa Bay reclamation plan is considered to be in conflict with the Tri Hita Karana principle that has been upheld by the Hindu community in Bali. This principle represents the harmonious relationship between humans and humans (Pawongan), humans and God (Parahyangan), and humans and nature (Palemahan).

Regarding this principle, the contradiction of the Palemahan principle is most clearly seen. However, other than that, the Benoa Bay reclamation plan is considered to be able to damage relations between the Balinese people (Peradah, 2014). This began to be demonstrated along with the conflict between the pros and cons of reclamation groups so that the culture of ngayah and mebanjar could be disrupted [8].

Meanwhile, the Parahyangan relationship also has the potential to erode given that most Hindu rituals relate to the sea and beaches, such as the Melasti and Ngaben ceremonies. The reclamation is considered to reduce the ritual land. In addition, the construction of a number of accommodation facilities implies the privatization of nature which is not impossible to reduce the social and cultural rights of the community. The use of cultural symbols in the pro-reclamation group's arguments is not necessarily accepted by the Balinese people.

The principle that was coined since 1966 is not only seen from the physical aspect alone, but is a principle of macro interrelation between humans, Sang Hyang Jagat Karana (God), and Bhuana (nature). This principle should be reflected in the culture and way of life of the Balinese people, which is not only demonstrated through the visible aspect. The importance of nature in the philosophy of Balinese Hindu society shows that there is a belief in Rta (Natural Law) as a buffer of the world that must be obeyed [9]. 
Table2. Pros and cons in the Benoa Bay Reclamation Plan

\begin{tabular}{|c|c|c|}
\hline & Pro Reclamation & Counter Reclamation \\
\hline Socio-cultural & $\begin{array}{l}\text { 1. Creating a new icon of } \\
\text { Bali tourism } \\
\text { 2. Preserving Balinese } \\
\text { culture }\end{array}$ & $\begin{array}{l}\text { 1. Replacing Tanah Lot, Uluwatu } \\
\text { Temple and Besakih Temple as } \\
\text { Bali's tourism icons } \\
\text { 2. Threatens the existence of a } \\
\text { holy place for Hindus in Bali }\end{array}$ \\
\hline Economical & $\begin{array}{l}\text { 1. Creating jobs } \\
\text { 2. Increasing Bali's land area }\end{array}$ & $\begin{array}{l}\text { 1. Eliminating the work of } \\
\text { fishermen and local tourism } \\
\text { businesses } \\
\text { 2. Dredging the Sawangan Beach } \\
\text { and Benoa Bay land as } \\
\text { reclamation material }\end{array}$ \\
\hline Ecological & $\begin{array}{l}\text { 1. Revitalization } \\
\text { 2. Save the Benoa Bay } \\
\text { mangrove forest } \\
\text { 3. Save the environment } \\
\text { 4. Tsunami disaster } \\
\text { anticipation and } \\
\text { mitigation }\end{array}$ & $\begin{array}{l}\text { 1. Reclamation or dredging the } \\
\text { sea } \\
\text { 2. Clearing the largest mangrove } \\
\text { forest in Bali } \\
\text { 3. Aggravate abrasion on the } \\
\text { surrounding beach } \\
\text { 4. Tsunami disaster anticipation } \\
\text { and mitigation should be } \\
\text { centered in the hills, not bays. }\end{array}$ \\
\hline
\end{tabular}

Source: Summarized based on the official Twitter account @ForBALI

In the case of Benoa Bay, the Balinese are actually confronted with a strong religious and cultural philosophy of having a "black" and "white" side. In this regard, the philosophy of "Rwa Bhineda" is reflected in the "Bali Reject Reclamation" debate. Rwa Bhineda is an attitude that believes in the existence of a world balance created by the bad and good sides of oneself and human life. By some, this causal debate is considered to have the potential to cause horizontal conflict. However, the debate between the "black" and "white" side of the Benoa Bay reclamation plan has also finally aroused some Balinese people to begin to behave and think critically about its natural sustainability as shown in Table 2 .

\section{Adat Movement in Bali}

ForBALI is the engine of the adat movements "Bali Tolak Reklamasi". ForBALI was initiated by people from various walks of life, ranging from environmental activists, musicians, to journalists who continue to develop involving various elements of Balinese society, both in Bali and outside Bali, and other people who care about Bali. Challenges in the form of rival regulations and intimidation actually make the knot movement increasingly tightened its ranks. In addition, the use of creative media, especially music, makes the "Bali Tolak Reklamasi" movement be able to be echoed cheerfully so that the flare of the movement becomes even brighter [8].

In the context of Balinese society, the involvement of various groups which is quite massive in "Bali Tolak Reklamasi" implies a separate phenomenon. Behind its beautiful face, Bali turns out to be a bit of an issue which then helps move those who care about the island. The focus of this discussion is "Bali Tolak Reklamasi" as a movement that has become a catalyst for the emergence of hidden problems in Bali and how the network of movements formed is able to present a response; not only from supporters of sympathetic movements, but also from those who are antipathy. 
The tone of the "Bali Tolak Reklamasi" movement is louder to be heard nationally and transnationally. Although the debate process continues to this day and the Benoa Bay reclamation project has not yet met a common ground for completion, the birth of the movement shows solidarity that knows no boundaries in a consistent period. This is certainly inseparable from several important factors that make "Bali Tolak Reklamasi" able to develop as a sizable social movement today [8].

According to Suardana, the ForBALI movement has been uniting environmental movements, citizen political movements; and the cultural movement became a movement to reject reclamation in Benoa Bay (Personal interview with I Wayan "Gendo" Suardana).

First, ForBALI was able to build people's participation, form a critical awareness of the people, so that the people's common sense said that the reclamation of Benoa Bay was bad. This was tested in 2014 through a community perception survey in Badung Regency. An interesting example is the question: "What is the most problematic in Badung?" The first sequence is security issues, the second is the lack of jobs. When asked their opinion about the reclamation of Benoa Bay which will build hotels and so on, so that it will absorb hundreds of thousands of workers, as PT TWBI claims in the AMDAL it is stated that it will absorb 180 thousand people, in the mass media it is said to absorb 200 thousand workers where $60 \%$ coming from outside Bali and $40 \%$ of the local population of Bali. Answer $80 \%$ of respondents said they rejected the reclamation project plan. This means that the level of public awareness is high, they need jobs but not by reclamation. In fact, so far the Balinese have been labeled very apathetic.

Second, ForBALI has pushed critical public awareness into political awareness. Presidential choice in 2014 most Balinese people hope that Jokowi has the courage of Jokowi to stop the reclamation project plan in Benoa Bay. The choice was based on consideration because Jokowi's track record was good when he was Mayor in Solo, and Governor in Jakarta.

Third, the ForBALI movement is an interesting phenomenon because for the first time an indigenous community movement has involved 39 indigenous villages with thousands of citizens, they criticize investments and then they refuse tourism investment. Previously, rejection of tourism development projects such as Bali Nirwana Resort (BNR) was only rejected by 1 traditional village; the construction of the 2012 Aqua factory was rejected by the Padangkerta traditional village, Karangasem; similarly Tahura was rejected by 1 traditional village.

Fourth, the ForBALI movement has encouraged the Parisada Hindu Dharma Indonesia (PHDI) institution, especially Paruman Sabha Pandita, which has decided that the Benoa Bay is a sacred area. PDHI has only made decisions twice, the first time, when the BNR case in Tanah Lot decided bisama (fatwa) about the sanctity of the temple: Pura village level sanctity radius $50 \mathrm{~m}$, Dang Kahyangan purity radius of $2 \mathrm{~km}$, and Sad Kahyangan like Besakih its purity radius $5 \mathrm{~km}$. Whereas the second decision of PDHI, has determined the Benoa Bay as a sacred area (there are 70 Hindu holy areas).

In short, many changes have resulted from the ForBALI movement, including building environmental awareness among young people. They are able to think critically, and no longer underestimate the protest movement, so they involve themselves in simple actions such as cleaning up the environment, cleaning up the beach. So, the participation of young people is very high, thus the ForBALI movement is now dominated by young people.

\section{Conclusion}

The conclusion we can note from the discussion about the adat movements for environmental justice in the Benoa Bay of Bali, first that ForBali was successful in temporarily thwarting the reclamation plan by PT TWBI. Second, the adat perspective on 
Tri Hita Karana became the philosophical foundation of the ForBALI movement. Third, ForBALI has succeeded in integrating environmental movements, political movements, and cultural movements into the spirit of resistance of indigenous peoples in the face of the hegemony of the power of neoliberal capitalism.

The movement of indigenous peoples to defend the Benoa Bay conservation area can be said to be an incarnation of critical public reasoning. This movement shows how important public participation is in protecting Indonesia's nature which is often under threat (Putri, 2016). There are three main arguments why reclamation was rejected by the Balinese people. The first concerns the biodiversity of the Mangrove forest area, Benoa Bay is the support of various species of life, seagrass beds and coral reefs. Second, in terms of Culture and Religion, Benoa Bay is a sacred area that holds a history of the formation of Shiva's Hindu religion and customs in Bali. Third from an economic perspective, Benoa Bay is an important location that supports the health of the South Bali coastline, most of which work as fishermen and marine tourism.

The latest development of the Benoa Bay reclamation project controversy ended after the Government through the Ministry of Maritime Affairs and Fisheries did not provide an extension of the location permit that has expired since August 26, 2018. An analysis of the environmental impact (AMDAL) of the Benoa Bay reclamation project was considered to be inappropriate because of the socio-cultural aspect, namely the rejection of community (Gumilang, 2018). The aspirations of the community as championed by the ForBALI movement have been accommodated by the State, thus the Balinese people won the struggle carried out for five years dealing with the private sector PT TWBI as an investor.

The news of the cancellation of the Benoa Bay reclamation project temporarily made the Balinese people especially relieved, because of the success of their efforts to avoid the Benoa Bay ecosystem from the threat of environmental damage in the name of development. In the framework of structuration, the State as a structure as well as an arena of contestation of the agency of interest groups dialectically carries out environmentally sound development, in connection with that a road map of natural resource management systems and a just and sustainable environment is needed.

The latest developments show, on the one hand, PT TWBI, after two or two years the location permit expired on August 26, 2018. The investor again pocketed the reclamation location permit No. B-795 / Men-KP / XI / 2018 from the Minister of Maritime Affairs and Fisheries issued November 29, 2018, so it is proceeding to prepare for the Benoa Bay reclamation project. While on the other hand, ForBALI after declaring its victory phase I due to the expiration of the 2018 location permit and investors have not yet fulfilled the socio-cultural aspects of the feasibility study.

At present, the ForBALI movement which is the mandate of Pasubayan Pakraman is preparing energy to enter a new phase of efforts to thwart the reclamation of the Benoa Bay. ForBALI's agenda going forward, is first: to push the results of the AMDAL study to be socio-culturally inappropriate. Second, submit a review of Perpres No. 51/2014 which is the "culprit" of the Benoa Bay reclamation discourse. Third, encourage the cancellation of Perpres No. 51/2014 to end the Benoa Bay reclamation polemic. While this reclamation issue stopped when the Minister of Maritime Affairs and Fisheries through the Minister of Maritime Affairs and Fisheries Regulation Number. 46 / Kepmen-KP / 2019 has determined that Benoa Bay is a maritime conservation area.

However, for the indigenous Balinese, this struggle is not over. Going forward we will still see the systematic and structured attempt to seize the Benoa Bay coastline. Therefore, the indigenous people's movement with ForBALI for environmental justice in Benoa Bay is entering a new phase. 


\section{References}

1. WALHI Tinjauan Lingkungan Hidup. Masa Depan Keadilan Ekologis di Tahun Politik. (2018)

2. S. Subekti, Perjuangan Masyarakat Adat untuk Keadilan Ekologis di Teluk Benoa, Bali. Endogami: Jurnal Ilmiah Kajian Antropologi, 3, 1 (2019)

3. ForBALI. "Mengapa Kami Menolak Reklamasi Teluk Benoa Bali”. $\mathrm{URL}=<$ http://www.forbali.org/id/mengapa-kami-menolak $>$

4. D. Harvey, Spaces of Capital: Towards a Critical Geography, (2001)

5. N. Castree, Neoliberalising Nature: The Logics of Deregulation and Regulation. Environment and Planning A 40: 131-152. (2008)

6. A. Wardana, Neoliberalisasi Kawasan Perairan Teluk Benoa: Sebuah Catatan Kritis atas Praksis Perlawanan di Bali. Ekologi Politis Air: Akses, Eksklusi, dan Resistensi. Wacana Jurnal Transformasi Sosial, 35 (2017)

7. G. J. Aditjondro, Bali Jakarta's Colony: Social and Ecological Impacts of Jakartabased Conglomerates in Bali Tourism Industry, Asia Research Centre, Murdoch University, Working Paper No. 58. Perth: Murdoch University (1995)

8. D. P. S. Suryani, Bali Tolak Reklamasi: Nada Pergerakan dari Pulau Dewata. Transnasionalisme: Peran Aktor Non Negara Dalam Hubungan Internasional. Ani Soetjipto (Ed.), (2018)

9. Peradah, Reklamasi Menggerus Adat Budaya Bali, Majalah Media Hindu 30 (2014) 